\title{
PHYSICAL MODEL ABOUT LASER IMPACT ON METALS AND ALLOYS
}

\author{
L. Lazov ${ }^{*}$, N. Angelov \\ Technical University of Gabrovo, Hadzhi Dimitar 4, 5300 Gabrovo, Bulgaria
}

\begin{abstract}
In this article we present our physical model for interaction of laser radiation with metals and alloys through structural changes, melting and vaporizing. We describe the interaction of laser radiation with materials, kinetic process of energy transmitting from free electrons to the crystal lattice and propagation of heat and the processing zone. We consider influence of optical and thermal properties over exploring process as they change with temperature and in the presence of mixtures.
\end{abstract}

Keywords: physical model, laser, metals, alloys, characteristics.

\section{INTRODUCTION}

Laser marking is a technological process in which a number of mutual connected physical phenomena and effects participate, and with interaction of laser radiation with material. These processes are connected with each other in many cases, i.e. they interact with each other. In order to manage the quality and the results of technology process, it is necessary to know these processes, as well as to know the principles connecting them. This knowledge is also necessary for successful monitoring of technological process in on-line regime and for selection of appropriate device for creating of technological systems.

Laser processing occurs in space and time and represents an impact of radiation on the material. Therefore, there is a need to explore the quantity of absorbed energy of laser radiation in substrate and its impact on the material. Figure 1 presents the principal scheme of energy balance of laser impact on metals and alloys. This gives us a notion of complexity of interaction of laser radiation with material and connections between these phenomena and processes [1].

As a result of interaction, electromagnetic energy is transformed in thermal energy. The efficiency of the entire process is strongly impacted by the losses that are a result of scattering and reflection. Only actually absorbed quantity has a direct impact on the technology method and the result of the processing. It is clear that with regards to the technological method of melting, vaporizing, or structural changes in the material, only a part of that energy makes a real contribution, because the losses appear as a result of convection, heat radiation and thermal conductivity.

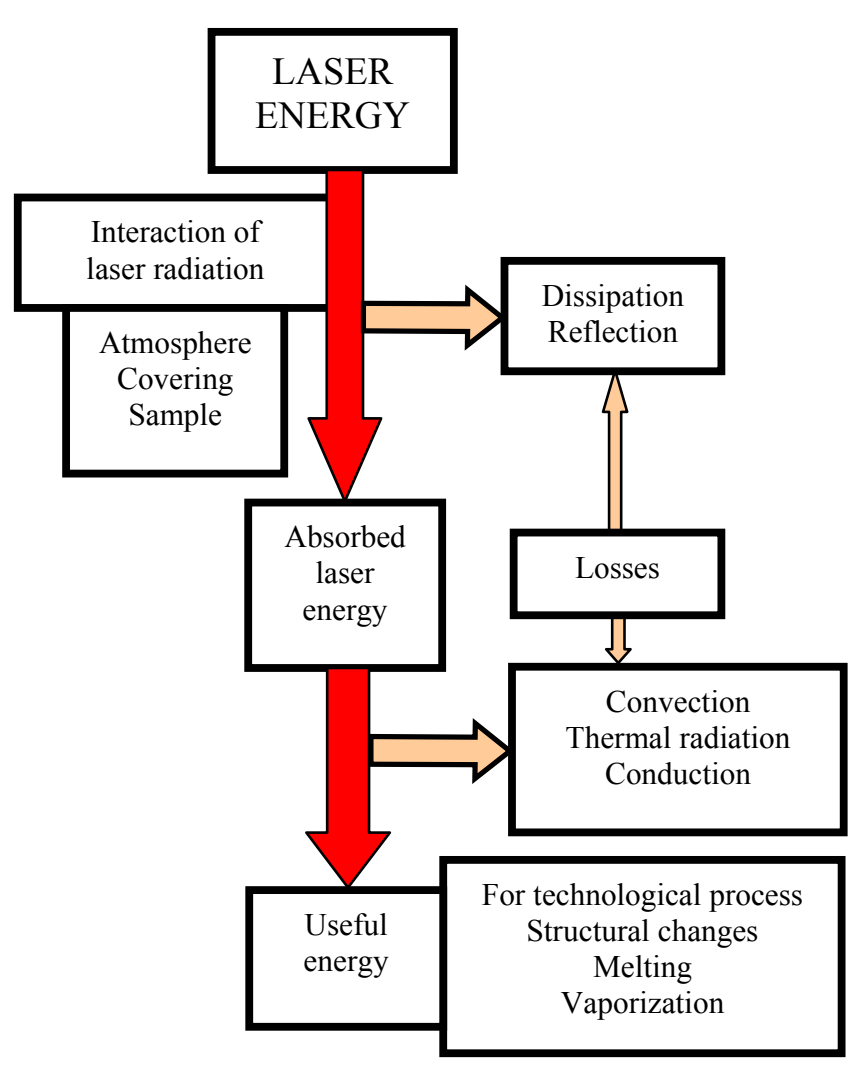

Figure 1. Principal scheme of energy balance of laser impact over metals and alloys

\section{PRESENTATION}

We may examine the absorbed energy as a degree of efficiency $\eta_{A}$ of total laser energy that falls onto the material, i.e. that is a part of falling energy 
which really participates in processing (structural changes, melting, vaporization in the unit volume). In certain references it is defined as a percentage of the total energy falling onto the material, necessary for concrete processing [1]. Under certain simplifications, if we ignore the conditions of working zone (convection, heat radiation and thermal conductivity) we assume that it is energy absorbed by the material.

\section{INTERACTION OF RADIATION WITH A SAMPLE}

The interaction of laser radiation with a sample is connected with the level of absorption $\mathrm{A} \%$, which is defined as a percentage of energy absorbed by material from the total energy falling onto the material. Optical depth of penetration $\delta$ is defined with absorption coefficient $\delta=1 / \alpha$. In this case we have exponential decrease of radiation intensity with depth $z$. For strong absorbing materials, such as metals and alloys, the depth of penetration $\delta$ is lower than wavelength $\lambda$ of falling radiation. Total energy that penetrates the material is absorbed and it does not depend on the thickness of the sample [1]. pends on:

The ratio of absorption according to [2] de-

- optical constants of material - coefficient of reflection $R$, absorption index $\kappa$;

- physical properties of laser radiation - wavelength $\lambda$, polarization, power density $q_{S}$;

- chemical composition of surface - oxides, nitride, graphite layers and so far;

- topography of surface (roughness);

as well as on the angle of radiation falling, temperature and aggregate state of material which is under impact.

The dependence of absorption ability $A$ on wavelength $\lambda$ for different materials at room temperature and angle of falling $0^{\circ}$ (towards normal) to the surface is presented in Fig. 2 [3].

We can see from the graph that absorption ability (except for $\mathrm{A} \ell$ ) decreases with an increase of wavelength. Differences in separate groups of metal which are under laser impact are clearly noticeable. Thus, for example, for precious metals $(\mathrm{Ag}, \mathrm{Cu}) \mathrm{ab}-$ sorption decreases very fast for wavelengths from visible spectrum, and for transition metals (Fe, Mo) the absorption change is more smooth and expands to the far infra-red range. $\mathrm{A} \ell$, which is a representative of polyvalent metals, has specific change of absorption with medium maximum for wavelength $\lambda=$ $0,84 \mu \mathrm{m}$ and almost for total range of wave lengths it has low absorption [1]. We can see on the graph for industry used lasers that there are great differences concerning the ratio of absorption for different metals. For example, iron (Fe) under impact from $\mathrm{CO}_{2}$-laser and $\mathrm{Nd}$ :YAG laser has absorption capability which changes 4 times and for $\mathrm{A} \ell$ this difference is insignificant. If we compare the ratio of absorption for $\mathrm{A} \ell$ under impact of diode lasers $(\lambda=0,808$ $0,940 \mu \mathrm{m})$ and $\mathrm{Nd}$ :YAG lasers, the diode ones have priority over others. The temperature of surface which is under processing is very important for increasing absorption of laser radiation falling on the material. This is easy to see in Fig. 3. If we reach the melting point then the absorption ability changes rapidly. This effect is noticed for $A \ell$ with different laser sources - $\mathrm{CO}_{2}$-laser, $\mathrm{Nd}$ :YAG laser and diode laser. For lasers with shorter wavelength that jump is significant comparing to $\mathrm{CO}_{2}$-laser. Other variables, which impact absorption, are polarization and angle of falling of the laser beam. (For laser radiation impacts, we have clearly expressed maximum for Brewster's angle, if electric vector $\vec{E}$ vibrates parallel to surface of falling. As for the impact with polarized laser radiation, if electric vector $\vec{E}$ vibrates normally to plane of falling we observe a smooth increase of absorption (see fig. 4). Nature of absorption maximum depends on wavelength $\lambda$. For $\lambda=10,6$ $\mu \mathrm{m}$ the maximum is narrow and has a value of about $80 \%$, and for visible range it is wide and about $30 \%$. The above effects are valid at low power density that does not allow creation of plasma-cloud over the processing surface.

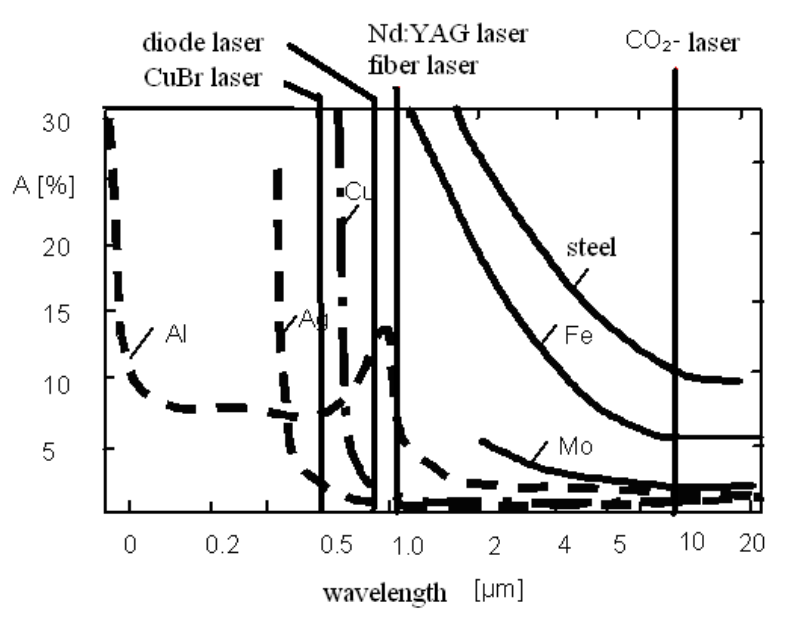

Figure 2. How absorption ability A depends on wavelength $\lambda$ for different metals and steel at room temperature and angle of falling along normally to the surface 


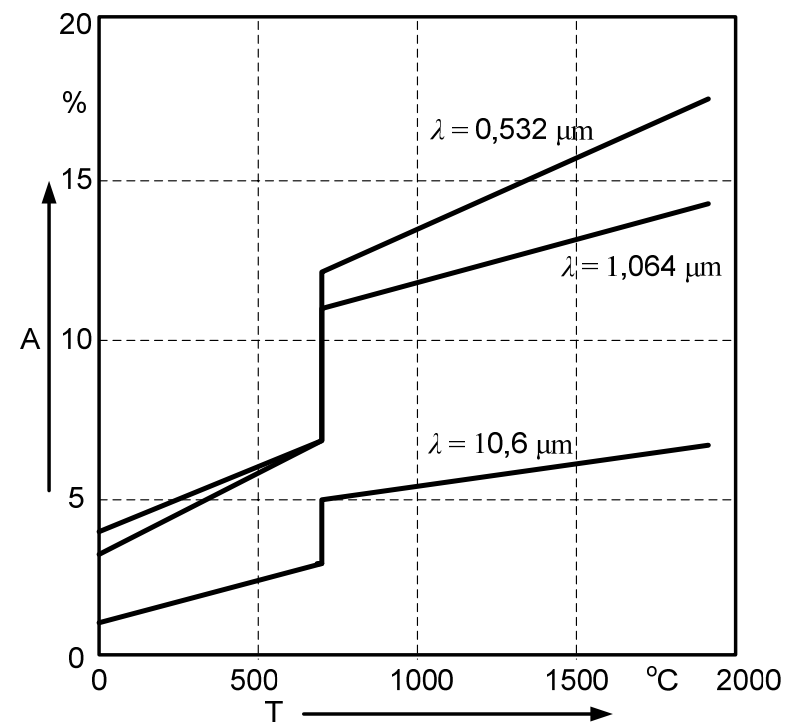

Figure 3. Graphics of dependence of absorption A on

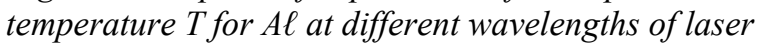
radiation

\section{THEORY OF THERMAL CONDUCTIVITY FOR METALS}

Concerning the impact with power density over certain threshold, when absorbed energy of processing zone is bigger than that and is scattered as a result of heat conductivity, we see that material starts to melt. The size of melting zone depends on parameters of processing, absorbed energy per unit length, but also on geometry and properties of the sample. For the purpose of marking, we need absorbed energy to generate such structural or phase changes in surface layer to obtain the quality of marking we need. Optimization of processing consists of selection of such parameters of processing (function of physical processes) which should cause appropriate temperature fields in material, ensuring desired geometry and quality of marking zone. By performing preliminary numeric calculation for temperature fields at laser impact over certain materials, when we notice the factors which influence processing, we may predict and optimize the final results. In the range of optical absorption of laser radiation in the metal, photon-electron interaction occurs, which results in absorption of electromagnetic energy, which is transformed into heat energy. Propagation of heat in the material is described by phenomenon of thermal conductivity.

Laser marking is known by its specific very small range of impact (several by ten $\mu \mathrm{m}$ ), big power density and short duration of impact. High temperature gradients for warming and cooling of the working zone are observed. Concerning duration of impact, the heat propagates to short distances in depth of the product and also on its surface. The final result is insignificant heat impacted zone as well as lack of convection losses.

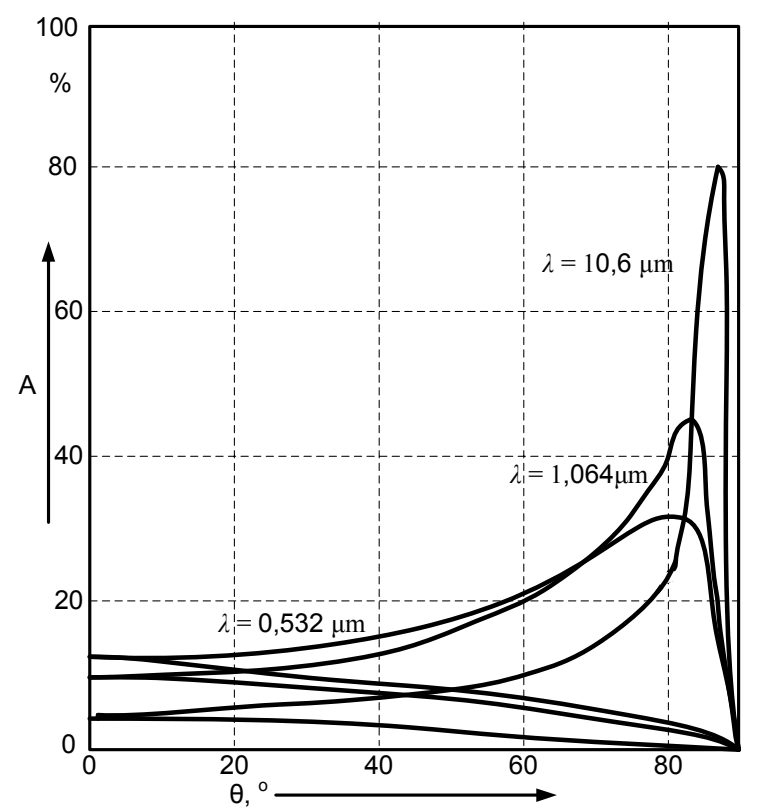

Figure 4. Graphs of the dependence of absorbance $A$ of the angle of incidence $\theta$ of laser radiation for $A \ell$ at different wavelengths

Penetrated in metal, laser radiation is completely absorbed by free electrons in thin layer under the surface with depth $0,1 \div 1,0 \mu \mathrm{m}$. That is the reason for their energy to increase and intensity of hits between them to grow. For the duration (time $t \sim 10^{-11} \mathrm{~s}$ ) from the beginning of the impact, they have delivered a very small part of that energy to crystal lattice. During that time strong overheating of electronic gas occurs $\left(T_{e}>>T_{i}\right.$, where $T_{e}$ is the temperature of electronic gas and $T_{i}$ is the temperature of crystal lattice). During that time, intensity of hits between free electrons and ions of crystal lattice increases as well as a stream of energy from electron gas to the lattice. For time $t_{r e l} \sim 10^{-9} \mathrm{~s}$ from the beginning of the impact, the temperature difference $\Delta T=T_{e}-T_{i}$ becomes minimum and the state in working volume has a characterization of shared temperature of metal $T$. The time $t_{r e l}$ is defined as the time of relaxation.

As explained already, the main part of transmission of heat in the metal at the laser impact occurs from electron conductivity. This means that heat processes of processing with laser radiation have the same physical nature as with the impact with traditional sources of heat. That gives the basis to de- 
scribe the heat propagation in the metal caused by laser radiation with classic theory of thermal conductivity.

As it was realized, optical depth of penetration of laser radiation in the metal is in the range of $10^{-7}$ $-10^{-8} \mathrm{~m}$ and it is considerably less than the length of heat diffusion ( $\delta<<\sqrt{4 a \tau}$ ). That is why in this case the laser radiation is considered as surface impacting heat source. Differential equation of heat conductivity is

$$
c \rho \frac{\partial T}{\partial t}=\operatorname{div}(k \operatorname{grad} T)+q_{S}(1-R) \alpha,
$$

whereby $T$ is temperature; $c$ - specific heat capacity; $\rho$ - density of material; $k$ - coefficient of heat conductivity; $q_{S}$ - surface power density of laser radiation; $R$ - coefficient of reflection; $\alpha$ - coefficient of absorption.

Equation (1) describes heat transfer through heat conductivity in the most general form. One initial and two limiting conditions are necessary for its application.

Initial condition - temperature of samples at the moment $\mathrm{t}=0$ is assumed to be equal to the ambient temperature

$T_{o}=$ const.

For laser processing, the following applies:

Condition of restriction of I stock

It defines distribution of temperature at the sample surface at every moment of the time

$T_{o}=$ const $\quad$ or $T_{o}=T_{o}(t)$.

Condition of restriction of II stock

It is given surface density of heat stream $q_{S}$ at every point of the surface of the sample at every moment of time. It is assumed that surface density $q_{s}$ in every point of head stream across the surface $q_{S}=$ const or $q_{S}=q_{S}(t)$ i.e. it is constant or is a function of time.

Since the surface density is proportional to temperature's gradient we may write:

$$
-\left.k\left(\frac{\partial T}{\partial x}\right)\right|_{S}=q_{S} \quad q_{S}=\text { const or } q_{S}=q_{S}(t) .
$$

Solution of the differential equation of heat conductivity at assigned initial (2) and limiting conditions (3) and (4) allow us to determine the temperature field of the sample in the given moment of time, as it is defined as function $T=T(x, y, z, t)$.

For analytic solution of differential equation we assume the following simplifications:
- Heat losses as result of radiation and convection are ignored (that is based at pulse laser processing);

- Dependence of temperature on optical and thermo-physical characteristics of materials is ignored.

With these limitations, the heat source in metal may be considered as moving surface's heat source with defined geometry of working zone. In this case analytic solution for equation of heat-conductivity is obtained.

The heat conductivity equation is not an analytic solution of a general case and that is why numerical methods are used for its resolution. Of many well known methods for exploration of temperature fields for laser impact on materials, the method of limited elements (4) is accepted as universal and well applied.

We have made certain theoretical calculations for the evaluation of described physical model, which we compared with concrete experimental results. A concrete technological process was examined - laser marking of products of carbon tool steels Y7, Y12 and alloyed tool steel P6M5. Initial parameters for numeric calculations were:

- diameter of working spot

- speed of marking

- frequency of pulse repetition

The trends of theoretical research are directed towards:

- Calculation of critical pulse energy for structural changes $E_{i m p(s c)}$ and critical power density $q_{S(s c)}$ for structural changes $(s c)$;

- Calculation of critical pulse energy for melting $E_{i m p(m)}$ and critical power density at melting $q_{S(m)}$;

- Calculation of critical pulse energy for vaporization $E_{i m p(t)}$ and critical power density $q_{S(t)}$ for vaporization.

The results of calculations are presented in table 1.

Table 1: Calculations of critical pulse energy and critical power density

\begin{tabular}{|l|l|l|l|}
\hline \multicolumn{1}{|c|}{$\begin{array}{c}\text { Material } \\
\text { Variable }\end{array}$} & \multicolumn{1}{c|}{$\mathrm{y} 7$} & \multicolumn{1}{c|}{$\mathrm{y} 12$} & \multicolumn{1}{c|}{ P6M5 } \\
\hline$E_{\text {imp }(s c)}, \mathrm{mJ}$ & 10,2 & 11,3 & 13,8 \\
\hline$q_{\mathrm{s}(\mathrm{sc})}, \mathrm{W} / \mathrm{m}^{2}$ & $2,84.10^{9}$ & $3,12.10^{9}$ & $3,83.10^{9}$ \\
\hline$E_{\text {imp }(m)}, \mathrm{mJ}$ & 19.9 & 21,9 & 26,8 \\
\hline$q_{s(m)}, \mathrm{W} / \mathrm{m}^{2}$ & $5,51.10^{9}$ & $6,09.10^{9}$ & $7,43.10^{9}$ \\
\hline$E_{\text {imp }(t)}, \mathrm{mJ}$ & 31,0 & 34,1 & 41,8 \\
\hline$q_{s(t)}, \mathrm{W} / \mathrm{m}^{2}$ & $8,60.10^{9}$ & $9,49.10^{9}$ & $1,16.10^{10}$ \\
\hline
\end{tabular}

Indicative results of calculations very well correlate with experimental data, obtained by marking of tool steels with this type of laser [5]. 


\section{CONCLUSION}

The considered model is applied for receiving preliminary engineering evaluations and prognosis of results of laser processing of metals and alloys with different laser sources. It helps selecting a laser source during construction of a technological system. Specific technological processes are being optimized by a mathematical model which was created on a physical basis.

\section{REFERENCES}

[1] F. Dausinger, Strahlwerkzeug Laser: Energieeinkopplung und Prozeßeffektivität, Universität Stuttgart, Habilitation 1995.

[2] Bergmann Ludwig, Schaefer Clemens Lehrbuch der Experimentalphysik, Band 3 Optik, Berlin: den Gruyter-Verlag 1987.

[3] Landolt, Bornstein Daten- und Funktionssammlung in Wissenschaft und Technik, Berlin, Springer-Verlag 1990.

[4] J. Xie, A. Kar, Mathematical modeling of melting during laser materials processing. Journal of Applied Physics, Nr. 81 (7), (1997) S.3015.

[5] www.pulslight.com

gon

\section{ФИЗИЧКИ МОДЕЛ ЗА ЛАСЕРСКО МАРКИРАњЕ МЕТАЛА И ЛЕГУРА}

Сажетак: У раду је представљен наш физички модел за интеракцију ласерског зрачења са металном легуром кроз структурне промјене, топљење и испаривање. Објашњена је интеракција ласерског зрачења са материјалима, кинетички процес преноса енергије слободних електрона у кристалну решетку и ширење топлоте у проводној зони. Разматран је утицај оптичких и термалних особина преко испитиваних процеса као што су промјене температуре и присуство смјесе.

Кључне ријечи: физички модел, ласер, метали, легуре, обиљежја. 